\title{
Using community-based interviews to determine population size, distribution and nest site characteristics of Pallas's fish eagle in north-east Bangladesh
}

\author{
Sayam U. Chowdhury, Mohammod Foysal and Nazim Uddin Khan
}

\begin{abstract}
Pallas's fish eagle Haliaeetus leucoryphus was recategorized from Vulnerable to Endangered on the IUCN Red List in 2017 because of evidence that there is only a single population, which is declining as a result of continuous, widespread loss and degradation of freshwater wetlands. To determine the species' status in Bangladesh, we conducted a large-scale community-based interview survey in north-east Bangladesh in 2017-2020. We also examined nest site habitat characteristics through field surveys and remotely sensed data. We conducted a total of 955 interviews in an area of $4,150 \mathrm{~km}^{2}$, through which we were able to determine the presence of 53 breeding pairs at a mean density of 1.2 nests per $100 \mathrm{~km}^{2}$. There was a higher nest density (3.7-4.8 nests per $\left.100 \mathrm{~km}^{2}\right)$ in some locations, which we identify as priority conservation areas. The majority of nests $(62.2 \%)$ were close together and on tall trees with an open canopy structure. Nests were located within or close to $(<100 \mathrm{~m})$ human settlements, and within $500 \mathrm{~m}$ of wetlands and rivers. Felling of nest trees, removal of nests by local people and loss of permanent wetlands (14.6\% during 2010-2020) appeared to be the main threats. High nesting density in our study area suggests that the freshwater wetlands in north-east Bangladesh possibly hold the largest population of Pallas's fish eagle globally.
\end{abstract}

Keywords Bangladesh, community-based interviews, conservation, Endangered, Haliaeetus leucoryphus, raptor, Pallas's fish eagle, wetlands

Supplementary material for this article is available at doi.org/10.1017/So030605321000314

SAYAm U. Chowdhury* (Corresponding author, (D) orcid.org/0000-0002-19018900, sayam_uc@yahoo.com), MoHAmmod Foysal and NAZIM UdDiN KHAN Bangladesh Raptor Research and Conservation Initiative, 16/C Tallabag, Sobhanbag, Mohammadpur, Dhaka 1207, Bangladesh

${ }^{*}$ Also at: Conservation Science Group, Department of Zoology, University of Cambridge, Cambridge, UK

Received 27 July 2020. Revision requested 15 October 2020.

Accepted 10 March 2021. First published online 20 December 2021.

\section{Introduction}

Dallas's fish eagle Haliaeetus leucoryphus was abundant In the 19th century along freshwater sources throughout Asia, particularly in north-east India and Bangladesh (Cripps, 1878; BirdLife International, 2001). In 2017 the species was recategorized from Vulnerable to Endangered on the IUCN Red List, with a global population estimate of 1,000-2,499 mature individuals (BirdLife International, 2020). The reason for this reassessment was primarily the continuous and widespread loss, degradation and disturbance of freshwater wetlands throughout the species' range, and new evidence that there is only a single, migratory population (Gilbert et al., 2014; Steele, 2017).

Prior to the recategorization of the species' conservation status, the rate of population decline was assumed to be lower than it actually was (BirdLife International, 2020). It was believed that the species comprised several isolated subpopulations, including a migratory breeding subpopulation north of the Himalayas in Mongolia and surrounding countries, and a non-migratory, resident breeding subpopulation south of the Himalayas in the Indian subcontinent. However, there is little evidence of breeding north of the Himalayas, and the supposedly separate populations south and north of the Himalayas are in fact a single migratory population that breeds in the Indian subcontinent in winter (October-April) and migrates north of the Himalayas, notably to Mongolia, in the summer (May-September; Naoroji, 2006; Gilbert et al., 2014; Steele, 2017; BirdLife International, 2020). Current knowledge suggests that the breeding range of Pallas's fish eagle encompasses India, Bangladesh, Nepal, Bhutan and possibly also Myanmar (Steele, 2017; BirdLife International, 2020). Based on previous observations (Naher \& Khan 2009; Sourav et al., 2011) and ad hoc records (SUC, unpubl. data, 2017) in north-east Bangladesh, we hypothesized that this region could be globally important for the species.

The study of small and isolated animal populations is often difficult, expensive and time-consuming using standard survey techniques (Turvey et al., 2016). Alternative and adaptive survey methods may therefore be necessary to determine the population status of threatened species (Turvey et al., 2014; Nash et al., 2016). Interview-based surveys that utilize the knowledge and experience of local people can be useful and are likely to provide accurate 


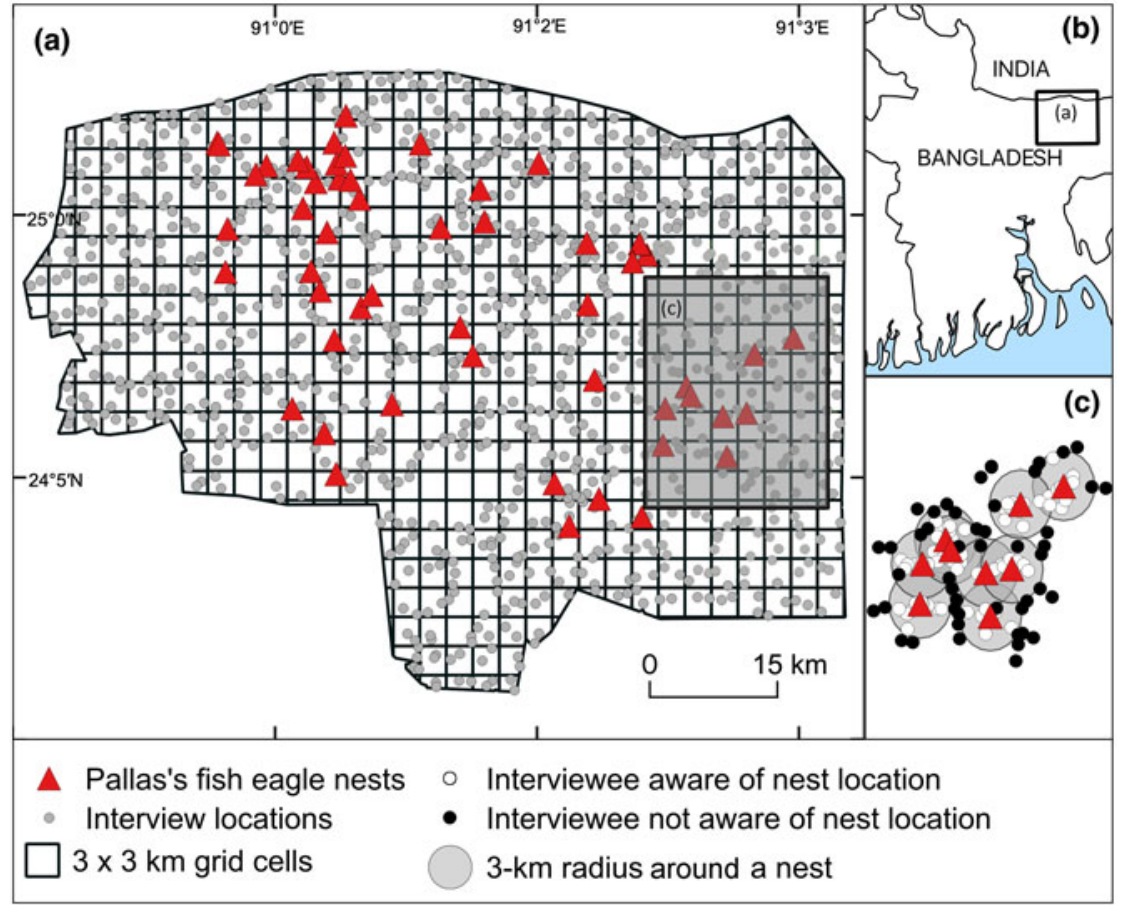

FIG. 1 (a) Locations of community-based interview surveys and Pallas's fish eagle Haliaeetus leucoryphus nests in (b) the study area in Sunamganj and Netrokona districts of north-east Bangladesh. The inset map (c) indicates the location of the initial exploratory survey within a $3-\mathrm{km}$ radius around nine known eagle nests. information about well-known, large and/or easily identifiable species or those with a high cultural or socio-economic value (Jones et al., 2008). However, there are potential errors and biases in the collection, interpretation and quantification of interview-based data, especially when these are gathered by untrained observers or if the study requires identification of less well-known species (McKelvey et al., 2008; Turvey et al., 2014).

Pallas's fish eagle is one of the largest eagles in the Indian subcontinent (Naoroji, 2006) and well known to people in north-east Bangladesh because of its loud and frequent calls during the breeding season (Chowdhury, 2018). In addition, the eagle has long been associated with the traditions, culture and religion of local communities, especially amongst Hindus, who celebrate the arrival of the eagle during the early dry season (August-September) and organize a festival, locally known as Raio Uutshav, in their villages (BirdLife International, 2001; Sourav et al., 2011). Because of these traditional linkages between Pallas's fish eagle and local communities, utilization of the same habitat and absence of any similar species in the area (Siddiqui et al., 2008) that could lead to misidentification, we were able to develop a community-based interview survey to determine the status of the species in north-east Bangladesh.

Recognizing the need for conservation action, we provide the first comprehensive survey of the species' breeding population and its habitat requirements in north-east Bangladesh. We conducted an extensive community-based interview survey to investigate spatial and temporal patterns in Pallas's fish eagle nesting and possible changes in the number of nesting territories. Using the information derived from interviews, we then visited presumed nesting locations to determine occupancy, nest site selection and habitat attributes. In addition, we conducted opportunistic surveys, compiled recent observations on previously reported Pallas's fish eagle breeding sites in Bangladesh and identified priority breeding areas in the north-east of the country. We discuss the significance of our findings for the conservation, monitoring and management of this species.

\section{Study area}

We conducted this study in the seasonally flooded freshwater wetlands (known locally as Haors) and humanmodified landscapes (agricultural fields and villages) of north-east Bangladesh, covering c. 4,150 $\mathrm{km}^{2}$. Ninety-two per cent of the study area is located within Sunamganj and $8 \%$ in Netrokona administrative districts of the Sylhet Division (Fig. 1). Sunamganj is near Cherrapunji in Meghalaya State of north-east India, with a mean annual rainfall of $>5,000 \mathrm{~mm}$, one of the highest levels of rainfall globally. During the rainy season (May-September), large areas of Sunamganj are submerged (Geisen et al., 2000). Most villagers live on areas of higher ground that are surrounded by trees. Mean monthly temperature and humidity in the study area range from $8.5^{\circ} \mathrm{C}$ and $64 \%$ in winter to $32{ }^{\circ} \mathrm{C}$ and $83 \%$ in summer (Geisen et al., 2000). Water levels fall during the dry season (October-April), resulting in numerous shallow waterbodies throughout the study area, with tree cover mainly in the villages. These circular floodplain depressions are important habitats for fish and waterbirds (Geisen et al., 2000; Muzaffar \& Ahmed, 2007), on which Pallas's fish eagle depends. 


\section{Methods}

\section{Community-based interview surveys}

Before conducting interviews, we obtained verbal consent from participants, informed them they could stop interviews at any point and explained their anonymity would be preserved. We conducted all interviews in Bangla (the local language), following, semi-structured interview guidelines (Newing, 2011). We randomly selected respondents in public spaces and in households within the villages. To ensure accurate identification of the species, we showed colour photographs of adult Pallas's fish eagles and played recordings of their breeding calls. We then asked the respondents if they knew of any current nest locations and whether the eagle had nested in their vicinity within the previous 20 years. We subsequently visited all locations where nests had been reported by respondents, and recorded nests as occupied only when we found an incubating adult or nestlings. In some cases, we found remnants of old nests, which we recorded as unoccupied. We also asked respondents if the population of Pallas's fish eagle in their area had increased or decreased in the previous 20 years, and what they considered to be the main threats to the eagle. To ensure systematic spatial sampling, we used a standard grid-based sampling approach with a uniform grid cell size (Harris et al., 2013). We conducted a pilot study to determine the most appropriate grid cell size in a $435 \mathrm{~km}^{2}$ area (10.5\% of the study area; Fig. $1 \mathrm{~b}$ ) in which we knew the locations of nine active Pallas's fish eagle nests (Sourav et al., 2011). Within this smaller area we undertook semi-structured interviews with the occupants of 135 households in 2017. During this pilot study, the households were in random directions and at distances of up to $5 \mathrm{~km}$ from the known Pallas's fish eagle nests. Almost all (95.1\%) of the 92 respondents who lived within a $3-\mathrm{km}$ radius of a nest (mean distance to nest $1,320 \pm \mathrm{SD} 800 \mathrm{~m}$ ) were able to provide accurate information on nest locations $\left(\chi^{2}=51.5, \mathrm{df}=1, \mathrm{P}<0.0001\right)$, whereas only $63.8 \%$ of the total of 135 respondents within a 5 - $\mathrm{km}$ radius (mean distance from nest 2,204 \pm SD 1,427 m) were aware of the nearest nest location $\left(\chi^{2}=6.27, \mathrm{df}=1\right.$, $\mathrm{P}=0.01$; Fig. 2). Thus, we chose $3 \times 3 \mathrm{~km}$ as the grid cell size. This resulted in 525 cells across the wider survey area, of which 23 were excluded as they comprised only open water without any villages or households. Detailed interview surveys were conducted in the remaining 502 grid cells during the breeding season of Pallas's fish eagle (November-March) over a 4-year period (190 interviews in 2017, 120 in 2018, 98 in 2019 and 94 in 2020), following the same protocol as in the pilot study. Within each grid cell we conducted 1-3 interviews (Fig. 1), during a total of 12 visits and 63 days. To avoid double counting any breeding pairs that may have relocated to a different nest site, we revisited each nest every year throughout the survey period.
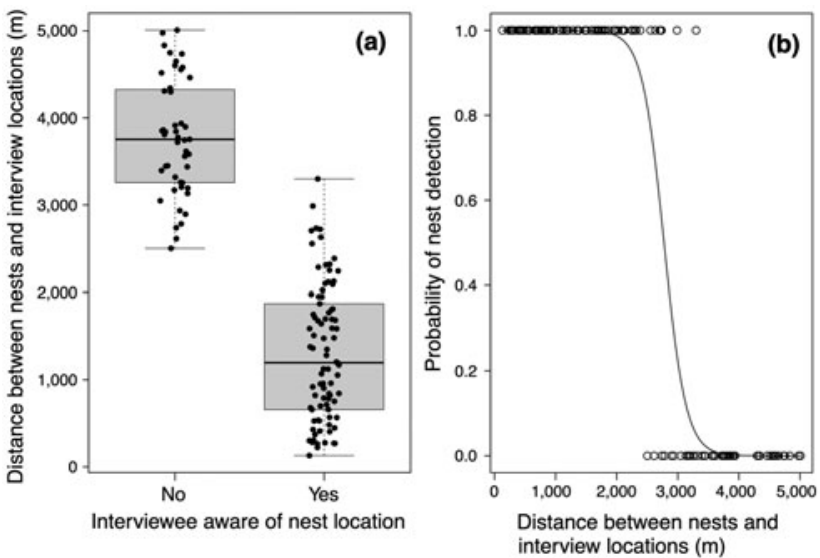

FIG. 2 (a) Boxplots indicating knowledge of respondents who lived within or outside a $3-\mathrm{km}$ radius from a nest regarding the presence or absence of a Pallas's fish eagle nest. (b) Logistic regression curve showing that as distance to the nest increases, the probability of nest detection through interview data decreases.

\section{Nest site characteristics}

At each occupied Pallas's fish eagle nest we recorded the geographical location with a GPS, the species, height, circumference at breast height and crown density of the nest tree, and the distance to the nearest human settlement, road, wetland and river. To determine differences between nesting trees and other available trees at the nest location, we collected the same information from an equal number of randomly chosen trees, which were at a fixed distance $(200 \mathrm{~m})$ but in a random direction from the nest tree (Hardey, 2006). We identified tree species according to Ahmed et al. (2009). We determined tree height using a clinometer and calculated distances remotely, using coordinates determined with a GPS, in QGIS 2.18 (QGIS Development Team, 2016). We visually estimated the crown density of the nest trees as the amount of light blocked by branches and foliage, in four categories: open (o-25\%), partially open (26-50\%), partially dense (51-75\%), and dense (76-100\%), following Miron \& Chowdhury (2019).

\section{Identifying priority areas for conservation}

Satellite tracking of three juvenile Pallas's fish eagles has shown that the mean home range in winter is $38.9 \pm \mathrm{SD}$ $43.8 \mathrm{~km}^{2}$ but juveniles appear to spend most of the first winter within $1 \mathrm{~km}$ of the nest location (Steele, 2017). The home range size of large raptors is closely related to food availability, especially during the breeding season when more resources are required to feed the young (Newton, 1979; Hardey, 2006). Here, we defined a circle with a $3-\mathrm{km}$ radius, with the nest location at the centre, as the primary nest habitat. Many nest sites used by different pairs were close together. When the $3-\mathrm{km}$ radius around four or more nest sites 
overlapped, we defined these sites as clusters, and used these clusters to identify priority areas for conservation.

\section{Nesting habitat characteristics}

We measured habitat characteristics within a $5-\mathrm{km}$ radius (3 $\mathrm{km}$ primary nesting habitat plus $2 \mathrm{~km}$ buffer; total area $78 \mathrm{~km}^{2}$ ) around each Pallas's fish eagle nest. Using Landsat satellite images from February 2010 and 2020 (USGS, 2020) and the semi-automatic classification plugin in QGIS, we defined four broad land-use categories: (1) permanent wetlands that held water during the driest months, including rivers, (2) agricultural fields, mainly dry paddy fields, (3) flooded paddy fields used to cultivate rice, and (4) other land use, including villages (Leroux et al., 2018). To compare habitat characteristics of the 53 nest sites with those of random sites within the study area, we generated 53 random points using the random point generator tool in QGIS, with a fixed minimum distance of $5 \mathrm{~km}$ between random points. We then analysed habitat characteristics within a $5-\mathrm{km}$ radius around each random point, as we did for the nest sites.

\section{Statistical analysis}

To evaluate the eagle's preferred nesting tree characteristics and nesting habitat, we fitted generalized linear models in which the presence or absence of an eagle nest at a nest site or a random site was the binary dependent variable, with binomial error distribution and logit link. We fitted all independent variables as fixed effects. We used the package Spatstat in $R$ 3.o (R Core Team, 2016) to analyse the local spatial association of Pallas's fish eagle nests. All statistical analyses were carried out in $R$.

\section{Results}

\section{Community-based interviews}

We (all authors) conducted a total of 955 interviews (including the initial survey of 135 households) across 502 grid cells $(1-3$ interviews per grid cell). Most respondents $(\mathrm{n}=830$, $87 \%, \chi^{2}=368, \mathrm{df}=1, \mathrm{P}<0.0001$ ) were able to correctly identify Pallas's fish eagle from photographs and recordings of its call. Almost a quarter of respondents $(n=238,24.9 \%)$ provided the location of an active Pallas's fish eagle nest. We verified that in 228 (95.8\%) cases, the indicated location did have an active eagle nest (some locations were indicated by several respondents). We found a total of 53 active Pallas's fish eagle nests within the study area (Fig. 1), with 106 adults and 38 nestlings.

Of the 830 respondents who identified Pallas's fish eagle correctly, $73 \%$ indicated that in the previous 20 years the
TABLE 1 Summary of community-based interview surveys with 955 respondents regarding their attitude towards Pallas's fish eagle Haliaeetus leucoryphus, and knowledge about nest sites, perceived population trend and threats.

\begin{tabular}{lc}
\hline Interview question/statement & Number of responses $(\%)^{1}$ \\
\hline $\begin{array}{l}\text { Species identification } \\
\text { Respondents correctly } \\
\text { identified the eagle }\end{array}$ & $830(86.9 \%$ of all respondents) \\
Attitudes towards the eagle & \\
Positive & $525(63.3 \%)$ \\
Neutral & $285(34.3 \%)$ \\
Negative & $20(2.4 \%)$ \\
Nest locations & $238(28.7 \%)$ \\
Respondents reporting nest & \\
$\quad$ locations & $228(95.8 \%$ of nest location \\
Reports of nest locations & reports) \\
$\quad$ verified during field surveys & \\
Perceived population trend & $606(73.0 \%)$ \\
Decreasing & $133(16.0 \%)$ \\
Not sure/no change & $91(11.0 \%)$ \\
Increasing & $176(21.2 \%)$ \\
Respondents who indicated & \\
nests had disappeared & \\
in the last 20 years & \\
Threats & \\
Nestlings fall from nests & \\
during storms & $211(25.4 \%)$ \\
Felling of nest trees & \\
Removal of nests by & \\
local people & $149(18.0 \%)$ \\
\hline
\end{tabular}

${ }^{1}$ Unless stated otherwise, per cent values indicate percentage of the 830 respondents who identified the species correctly.

population may have declined, $16 \%$ did not know and only $11 \%$ indicated an increase in the number of breeding pairs (Table 1). Eighteen per cent of the 830 respondents mentioned that nest trees in their area had been cut down and the eagles did not return to nest in subsequent years, except for 12 cases when a nest was re-built in a nearby tree. A small number $(2.3 \%)$ of respondents reported that the owner of a nest tree destroyed Pallas's fish eagle nests in retaliation for predation on domestic poultry chicks and ducklings by adult eagles. Some (26.6\%) of the respondents indicated that the pre-monsoon storms in MarchApril cause considerable mortality of nestlings as many fall from the nest.

The majority ( $83 \%$ ) of nest sites were used by eagles during the last 50 years or more, and in $28 \%$ of these sites, the same nest trees were used in the previous 5-15 years. One hundred and seventy-six respondents $(21.2 \%, \mathrm{n}=830)$ reported the loss of 47 Pallas's fish eagle nests from their villages (Fig. 3). These breeding pairs relocated or were extirpated in the previous 20 years. The reasons behind this decline or shift could not be determined, but felling of $16(34 \%)$ nest trees was reported by the respondents. 

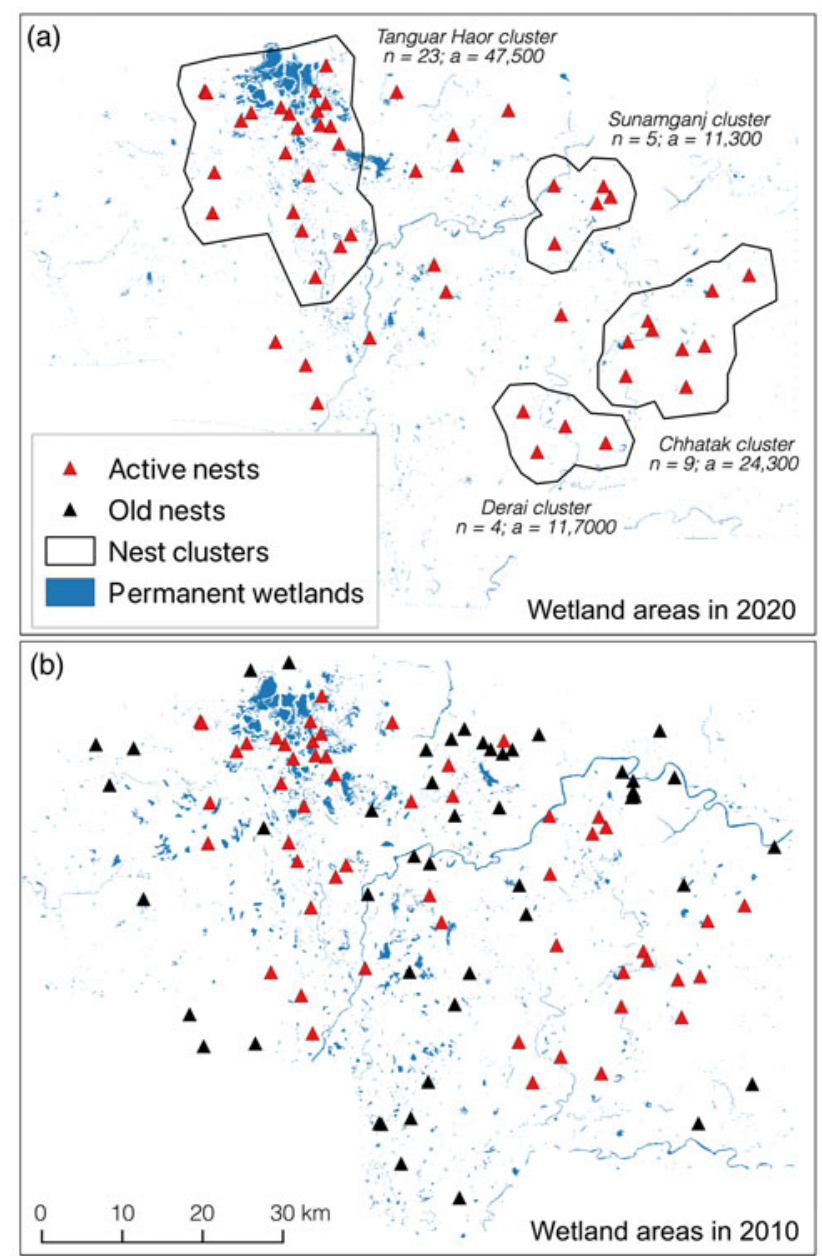

FIG. 3 (a) Distribution of nest locations and permanent wetland areas (including rivers) in 2020, and four clusters, where $n$ indicates number of nests and $a$ the area (ha) of the cluster. (b) Permanent wetland areas in 2010, and locations of Pallas's fish eagle nests that were lost or abandoned since the early 200os, based on interview survey results and current nest locations. The distribution of permanent wetland areas in 2010 indicates that many extirpated or relocated nests were in sites with permanent wetland areas.

\section{Nesting habitat}

We collected habitat data at the locations of 53 Pallas's fish eagle nests, of which $47(88.6 \%)$ were in trees. The most commonly used tree species were the red silk cotton tree Bombax ceiba with 14 nests $(26.4 \%)$ and the rain tree Samanea saman with seven nests (13.2\%). An additional 11 tree species were used in smaller numbers (1-4 nests), and six nests $(11.3 \%)$ were on telecommunication towers (Table 2). The mean circumference at breast height of the nesting trees was $195 \pm$ SD $81 \mathrm{~cm}$ (range: $90-450 \mathrm{~cm}$ ) and the mean height was $13.5 \pm \mathrm{SD} 4.4 \mathrm{~m}$ (range 6.0-21.3 m). Of the 47 nest trees, $46.8 \%$ had an open, $42.5 \%$ a partially open and $10.6 \%$ a partially dense canopy. Nests were positioned either at the top or within $2 \mathrm{~m}$ of the highest point of the tree, depending on the suitability of the branches to support the nest. Nests on communication towers (height: 30-42 m, n =6) were positioned on the top platform.

Most (83\%) nests were located within $100 \mathrm{~m}$ of human settlements $\left(\chi^{2}=14.8, \mathrm{df}=1, \mathrm{P}<0.0001\right)$, with a mean distance of $71 \pm$ SD $189 \mathrm{~m}$ (range $1-311 \mathrm{~m} ; \mathrm{n}=53$ ). Similarly, human activities such as agriculture were recorded in the vicinity of $96 \%$ of all nests (range $1-200 \mathrm{~m} ; \mathrm{n}=53$ ), and $26 \%$ of nests were positioned within $500 \mathrm{~m}$ of roads. Sixty-two per cent $(n=33)$ and $49 \%(n=26)$ of nests were within $500 \mathrm{~m}$ of rivers (mean distance $1,320 \pm \mathrm{SD} 2,146 \mathrm{~m}$, $\mathrm{n}=53$ ) and wetlands (mean distance $801 \pm \mathrm{SD} 780 \mathrm{~m}, \mathrm{n}=53$ ), respectively (Table 2). Overall, logistic regressions for effects on the presence of Pallas's fish eagle nests compared to random sites $200 \mathrm{~m}$ away from the nest indicated a significant effect $\left(r^{2}=0.69, F=69, \mathrm{P}<0.001\right)$ of the nest tree's height, circumference at breast height and crown density (Table 3 ).

Permanent wetlands within a $5-\mathrm{km}$ radius (mean area $5.57 \pm$ SD $6.80 \mathrm{~km}^{2}, \mathrm{n}=53$ ) had a significant positive effect on Pallas's fish eagle nest habitat selection, compared with random locations at a minimum distance of $5 \mathrm{~km}$ from a nest. Other habitat variables such as agricultural lands (mean area $11.9 \pm \mathrm{SD} 5.33 \mathrm{~km}^{2}$ ), paddy fields (mean area $54.9 \pm$ SD $8.37 \mathrm{~km}^{2}$ ), and other land use (mean area $13.5 \pm$ SD $6.28 \mathrm{~km}^{2}$ ) had weak effects (Table 3 ).

\section{Aggregated nesting pattern and priority areas}

The 53 active Pallas's fish eagle nests were distributed across a total of 10 subdistricts of Sunamganj and Netrokona districts in north-east Bangladesh, with the maximum number of nests located in Tahirpur subdistrict $(22.6 \%, \mathrm{n}=12)$. The eagles tended to nest near each other $(\beta=1.05,95 \%$ $\mathrm{CI}=1.01-1.10$; Fig. 3$)$, with $62.3 \%(\mathrm{n}=33)$ of nests within $3 \mathrm{~km}$ of one or more nests (Supplementary Fig. 1; Clark and Evans test: $R=0.36, \mathrm{P}=0.001 ; R<1$ indicates a non-uniform pattern). The overall mean nest density was 1.2 nests per $100 \mathrm{~km}^{2}$, with four nest clusters $(78 \%$ of all nests, $n=41$ ); Tanguar Haor cluster (Fig. 3 ) had the highest nest density ( 4.8 nests per $100 \mathrm{~km}^{2}, \mathrm{n}=23$ ), followed by Chhatak cluster $\left(3.7\right.$ nests per $100 \mathrm{~km}^{2}, \mathrm{n}=9$ ).

\section{Discussion}

\section{Community-based interview surveys}

Our findings demonstrate that data obtained through large-scale community-based interviews can be verified by field surveys confirming the presence or absence of the target species (Turvey et al., 2014; Nash et al., 2016). Using this approach, we provide a comprehensive overview of the population and conservation status of Pallas's fish eagle in north-east Bangladesh, which is the only remaining 
TABLE 2 Nest tree and habitat characteristics (mean \pm SD) at Pallas's fish eagle nest sites and random sites in north-east Bangladesh.

\begin{tabular}{|c|c|c|c|c|c|c|c|c|}
\hline Tree species/site & $\mathrm{n}$ & $\begin{array}{l}\text { Tree circumfer- } \\
\text { ence at breast } \\
\text { height }(\mathrm{cm})\end{array}$ & $\begin{array}{l}\text { Tree } \\
\text { height } \\
(\mathrm{m})\end{array}$ & $\begin{array}{l}\text { Distance to } \\
\text { wetland (m) }\end{array}$ & $\begin{array}{l}\text { Distance to } \\
\text { river }(\mathrm{m})\end{array}$ & $\begin{array}{l}\text { Distance to } \\
\text { human } \\
\text { activity }(\mathrm{m})\end{array}$ & $\begin{array}{l}\text { Distance to } \\
\text { road }(\mathrm{m})\end{array}$ & $\begin{array}{l}\text { Distance to } \\
\text { human } \\
\text { settlement }(\mathrm{m})\end{array}$ \\
\hline Bombax ceiba & 14 & $204 \pm 58$ & $16.7 \pm 3.7$ & $966 \pm 889$ & $2,305 \pm 3,026$ & $14.2 \pm 13.8$ & $148.0 \pm 111.9$ & $49.1 \pm 63.4$ \\
\hline Samanea saman & 7 & $228 \pm 73$ & $15.7 \pm 4.0$ & $786 \pm 1,250$ & $1,244 \pm 1,685$ & $9.1 \pm 14.0$ & $165.1 \pm 300.8$ & $22.3 \pm 30.5$ \\
\hline Crataeva nurvala & 4 & $153 \pm 26$ & $9.4 \pm 1.7$ & $1,300 \pm 429$ & $68 \pm 83$ & $27.3 \pm 88.4$ & $352.4 \pm 575.5$ & $56.3 \pm 183.3$ \\
\hline Albizia procera & 4 & $191 \pm 66$ & $10.8 \pm 1.2$ & $715 \pm 356$ & $1,860 \pm 2,188$ & $33.5 \pm 57.7$ & $343.8 \pm 385.9$ & $14.5 \pm 17.4$ \\
\hline $\begin{array}{l}\text { Neolamarckia } \\
\text { cadamba }\end{array}$ & 4 & $117 \pm 37$ & $11.0 \pm 4.2$ & $597 \pm 212$ & $238 \pm 357$ & $4.8 \pm 3.8$ & $191.5 \pm 345.2$ & $48.0 \pm 72.9$ \\
\hline Trewia nudiflora & 3 & $132 \pm 42$ & $13.2 \pm 4.1$ & $696 \pm 374$ & $66 \pm 40$ & $5.3 \pm 3.8$ & $57.6 \pm 55.0$ & $19.9 \pm 8.8$ \\
\hline Ficus infectoria & 3 & $132 \pm 175$ & $13.2 \pm 2.7$ & $696 \pm 609$ & $66 \pm 3,078$ & $5.3 \pm 14.4$ & $57.6 \pm 17.0$ & $19.9 \pm 24.0$ \\
\hline Pongamia pinnata & 2 & $132 \pm 112$ & $13.2 \pm 3.3$ & $696 \pm 163$ & $66 \pm 11$ & $5.3 \pm 84.9$ & $57.6 \pm 62.9$ & $19.9 \pm 919.2$ \\
\hline Alstonia scholaris & 2 & $194 \pm 59$ & $11.0 \pm 2.1$ & $1,596 \pm 1,844$ & $2,332 \pm 3,104$ & $8.0 \pm 9.9$ & $179.0 \pm 172.5$ & $54.5 \pm 64.4$ \\
\hline Terminalia arjuna & 1 & $172 \pm 172$ & $12.2 \pm 0.0$ & $65 \pm 0$ & $745 \pm 0$ & $1.0 \pm 0.0$ & $412.0 \pm 0.0$ & $5.0 \pm 0.0$ \\
\hline Syzygium cumini & 1 & $414 \pm 0$ & $9.1 \pm 0.0$ & $513 \pm 0$ & $5 \pm 0$ & $15.0 \pm 0.0$ & $308.0 \pm 0.0$ & $237.0 \pm 0.0$ \\
\hline $\begin{array}{l}\text { Albizia } \\
\quad \text { richardiana }\end{array}$ & 1 & $280 \pm 0$ & $12.5 \pm 0.0$ & $1,100 \pm 0$ & $4,980 \pm 0$ & $5.0 \pm 0.0$ & $5.0 \pm 0.0$ & $11.0 \pm 0.0$ \\
\hline Albizia lebbeck & 1 & $145 \pm 0$ & $13.0 \pm 0.0$ & $1,210 \pm 0$ & $851 \pm 0$ & $10.0 \pm 0.0$ & $22.0 \pm 0.0$ & $31.0 \pm 0.0$ \\
\hline $\begin{array}{l}\text { Communication } \\
\text { towers }\end{array}$ & 6 & & $33.3 \pm 5.2$ & $868 \pm 777$ & $848 \pm 1,679$ & $19.7 \pm 31.2$ & $104.3 \pm 147.3$ & $15.0 \pm 18.3$ \\
\hline All nest sites & 53 & $195 \pm 81$ & $13.5 \pm 4.4$ & $801 \pm 782$ & $1,320 \pm 2,147$ & $21.9 \pm 37.6$ & $205.8 \pm 285.9$ & $71.0 \pm 189.2$ \\
\hline Random sites & 53 & $8 \pm 82$ & $6.1 \pm 4.4$ & $917 \pm 752$ & $1,454 \pm 2,230$ & $17.7 \pm 39.0$ & $227.6 \pm 300.5$ & $80.7 \pm 201.4$ \\
\hline
\end{tabular}

TABLE 3 Results of logistic regression models testing for effects on the presence of occupied nests at nest locations and random sites of tree characteristics (height, circumference at breast height and crown density), human presence (distance from road, human settlement and human activity) and waterbodies (rivers and wetlands), and habitat attributes (permanent wetlands, agricultural fields, paddy fields and other land use) on the occurrence of Pallas's fish eagle nests. Significant effects are indicated with *.

\begin{tabular}{|c|c|c|c|c|}
\hline Model term & $\begin{array}{l}\text { Parameter } \\
\text { estimate }\end{array}$ & SE & $z$ value & $\begin{array}{l}\operatorname{Pr} \\
(>|z|)\end{array}$ \\
\hline \multicolumn{5}{|c|}{$\begin{array}{l}53 \text { nest sites compared to } 53 \text { random sites ( } 200 \mathrm{~m} \text { away from the } \\
\text { nest in a random direction) }\end{array}$} \\
\hline (Intercept) & -1.22 & 6.05 & & \\
\hline $\begin{array}{l}\text { Circumference at breast } \\
\text { height }\end{array}$ & 6.49 & 3.25 & 1.999 & $0.0457^{\star}$ \\
\hline Height & 1.45 & 7.37 & 1.971 & $0.0487^{*}$ \\
\hline Crown density & -1.91 & 8.19 & -2.326 & $0.0200^{*}$ \\
\hline Distance to wetland & 1.65 & 1.52 & 1.088 & 0.2765 \\
\hline Distance to river & -5.67 & 5.71 & -0.993 & 0.3205 \\
\hline $\begin{array}{l}\text { Distance to human } \\
\text { activity }\end{array}$ & 3.03 & 3.23 & 0.936 & 0.3493 \\
\hline Distance to road & 5.67 & 3.28 & 0.173 & 0.8628 \\
\hline $\begin{array}{l}\text { Distance to human } \\
\text { settlements }\end{array}$ & -1.60 & 4.84 & -0.332 & 0.7401 \\
\hline \multicolumn{5}{|c|}{$\begin{array}{l}\text { Habitat attributes within a } 5-\mathrm{km} \text { radius of } 53 \text { nest sites, } \\
\text { compared to } 53 \text { random sites ( } \geq 5 \mathrm{~km} \text { away from the nest site) }\end{array}$} \\
\hline (Intercept) & -23.02 & 10.16 & & \\
\hline $\begin{array}{l}\text { Permanent } \\
\text { wetlands }\end{array}$ & 0.48 & 0.16 & 3.055 & $0.0023^{\star}$ \\
\hline Agricultural fields & 0.25 & 0.12 & 1.989 & $0.0467^{\star}$ \\
\hline Paddy fields & 0.27 & 0.12 & 2.290 & $0.0220^{*}$ \\
\hline Other land use & 0.25 & 0.12 & 2.074 & $0.0381^{*}$ \\
\hline
\end{tabular}

stronghold of this species. For locally popular or charismatic species, community-based interview surveys can be a robust sampling method. Pallas's fish eagle was accurately identified by the majority of respondents, suggesting that an interview-based survey could be used in other parts of the species' range to determine population size and assess threats. Such information is vital to develop long-term conservation and management strategies for threatened species, and to examine the effects of anthropogenic disturbance (Newton, 1979; Harris et al., 2013).

\section{Nesting habitat and density}

Although Pallas's fish eagle is widely distributed, its breeding ecology remains little studied (BirdLife International, 2001; Naoroji, 2006; Steele, 2017). Our study is one of the first to examine the nesting habitat requirements of the species. We found that Pallas's fish eagle typically prefers the tallest trees within the nesting territory; in our study the mean height of nesting trees was $13.4 \mathrm{~m}$ (Table 3). Most nests were within or close to $(<100 \mathrm{~m})$ human settlements or roads, suggesting the species is relatively tolerant of human presence and associated disturbance (Supplementary Fig. 2). Our regression models (Table 3 ) did not find a correlation with the surrounding habitat (e.g. human settlements), possibly because of the uniform habitat characteristics around the nest sites and short distance $(200 \mathrm{~m})$ between nest and random sites. Future studies could examine nesting habitat preferences at larger spatial scales and select random sites 
further away from nest sites. We confirmed a positive association between the Pallas's fish eagle and waterbodies (Fig. 3), and, unlike most previous studies, we quantified the distances between eagle nest sites and wetland areas (Naoroji, 2006; Sourav et al., 2011).

Ours is the first analysis of the spacing of Pallas's fish eagle nests, demonstrating a clustered pattern (Supplementary Fig. 1). This aggregation is possibly driven by availability of food resources and suitable nest trees (Newton, 1979), which in the study area are located primarily in and around villages. This assumption is also supported by the differences in wetland areas and density of nests at the Tanguar Haor and Derai clusters (Fig. 3). It is possible that isolated nests outside these clusters are in locations that only just fulfil the species' requirements for food and suitable nest trees, limiting breeding success (Newton, 1979; Hardey, 2006).

The results of our survey suggest that the majority of breeding pairs may have used the same nesting site and nest trees for many years if not disturbed. It remains unclear what happens to the offspring as we did not find any evidence of offspring reoccupying the same breeding areas. It has been hypothesized that breeding sites are generally used by pairs or possibly their offspring for many years in succession (BirdLife International, 2001). However, two satellitetagged juveniles did not return to their natal territory in India; one migrated to Myanmar and the signal of the other was lost (Steele, 2017). Marking young birds at the nest with coloured leg rings or wing tags could facilitate individual monitoring, verification of site fidelity and population estimates. Satellite telemetry studies should be undertaken to examine migratory linkages between breeding and nonbreeding sites.

\section{Population status in Bangladesh}

Prior to our study, it was thought that Bangladesh accounted for a small proportion of the global breeding population of Pallas's fish eagle (BirdLife International, 2001; Steele, 2017). Sourav et al. (2011) recorded 11 nests during opportunistic surveys in 2009 in Sunamganj district and cited 22 nests in 1999 and 15 in 2001-2002 from previous studies. Most of these reports were concentrated around Tanguar Haor. In 20032004, five nests were found in Netrokona district (Naher \& Khan, 2009). Our study covered a larger area than these studies and used a more comprehensive survey methodology, combining community-based interviews and field surveys of nest locations. The presence of 53 nests within the study area suggests that Sunamganj and Netrokona districts are more important, both nationally and globally, for nesting Pallas's fish eagles than previously thought. However, this population has declined since the early 1980s; previous estimates suggested that in the early 1980s, 61 villages around Tanguar Hoar had at least one nesting pair (Sourav et al., 2011). Our community-based interviews suggested that 47 breeding pairs have disappeared from the area since the early 2000 .

There are only a few recent (post-2000) breeding records outside these two districts. These include a pair that bred in Hail Haor, Moulovibazar district, in the north-east, during 2010-2012, but the nesting tree was felled and the area was abandoned in subsequent years (SUC, pers. obs., 2019). Another pair bred in Moulovibazar city until 2015 when the nest was destroyed during a storm (S.S. Inam, pers. comm., 2020). However, a pair was found in southern Hail Haor in February 2020 (M. Foysal, pers. obs., 2020). These recent records suggest that isolated pairs may breed outside our study area in north-east Bangladesh, and further surveys elsewhere should be carried out. The most recent nesting record in Bangladesh outside the north-eastern districts was of a pair in the freshwater-dominated area in the northern fringe of the Sundarbans mangrove forest in 2006 (R. Halder, pers. comm., 2011). The lack of breeding records from outside our study area indicates that the area holds the most important, and possibly the only, permanent breeding population in the country.

\section{Threats}

The loss and degradation of wetlands, felling of nesting trees, shortage of prey, uncontrolled spread of water hyacinth Eichhornia crassipes and the use of pesticides have been identified as principal causes of the decline of Pallas's fish eagle (BirdLife International, 2001; Naoroji, 2006; Rahmani et al., 2012). However, the effects of intentional removal of nests by local people in retaliation for predation on domestic poultry chicks and ducklings, and high mortality of nestlings during pre-monsoon storms, have not yet been quantified. Increased domestic fowl populations (Sarkar et al., 2017) in the agro-ecological landscapes of north-east Bangladesh may have led to increasing negative interactions between local people and Pallas's fish eagles.

Apart from isolated incidents of intentional nest damage, people in general $(63.3 \%, \mathrm{n}=830)$ had positive attitudes towards Pallas's fish eagle. Historical notes dated from the early 19th century also indicate that people did not persecute Pallas's fish eagles (BirdLife International, 2001), and Cripps (1878) was asked not to shoot nesting Pallas's fish eagles in the property of a local person in north-east Bangladesh.

Results of our remote sensing analysis show that the extent of permanent wetlands in the study area has declined by at least $14.7 \%$ during 2010-2020 (Fig. 3b). Similarly, other studies of land-use change reported large-scale degradation of wetlands in the area. During 1980-2010, c. $40 \%$ of forested and wetland areas in Tanguar Haor have been converted to agricultural land (Haque \& Basak, 2017). A study of seasonal freshwater wetlands in north-east Bangladesh reported the loss of $6.9 \%$ of waterbodies during 
2000-2008 (Salauddin \& Islam, 2011). Degradation, disturbance and conversion of seasonal freshwater wetlands thus continue to threaten Pallas's fish eagle.

\section{Conservation implications}

There is an urgent need to develop methods to assess and monitor the status of Pallas's fish eagle at a larger scale. Our interview surveys identified many previously unknown nests and provided new evidence on the species' continued decline and threats. We therefore encourage the application of similar large-scale community-based interview surveys to assess the status of Pallas's fish eagle across its breeding range. Future surveys could involve lowland districts such as Hobigonj, Moulavibazar and Sylhet.

Our observations on nest site fidelity were consistent with previous reports (BirdLife International, 2001; Steele, 2017). This site fidelity and the overall positive attitude of local communities could benefit the conservation of Pallas's fish eagle, although species with strong site fidelity may also be more vulnerable to habitat degradation (Warkentin \& Hernández, 1996). Tanguar Haor is recognized as a Ramsar site and an East Asian-Australasian Flyway Partnership Network site. The protected area (9,500 ha), however, covers only $20 \%$ of the Tanguar Haor eagle nest cluster (Fig. 1), meaning most of Pallas's fish eagle nests are located outside the only protected area in Sunamganj district. We therefore recommend a reassessment of the boundary of the Tanguar Haor protected area and the implementation of an evidence-based management plan following the guidelines provided by the Ramsar Convention (Ramsar Convention Secretariat, 2007). In addition, wetland restoration schemes and sustainable landuse practices outlined in the 6th National Report to the Convention on Biological Diversity (MoEF, 2019) should be implemented in other key breeding areas (Fig. 3).

Our study highlights the importance of tall trees near wetland areas, underscoring the need to preserve native trees such as B. ceiba. Existing nest trees within and outside villages should be protected. The Bangladesh Raptor Research and Conservation Initiative initiated a nest guardian scheme in villages around Sunamganj city and organized a workshop in November 2020. The impact of this intervention will be investigated further, and if found effective, this scheme could be expanded to other areas (SUC, unpubl. data, 2020). A total of nine nests were in sacred, communityprotected sites such as cemeteries, shrines and temples, where the preservation of tall trees creates suitable nesting places for Pallas's fish eagle. To ensure continued availability of nest trees, suitable tree species (Table 2) should be planted, particularly in sacred sites. In addition, further conservation action should include strategies for the rehabilitation of nestlings that fall from the nest during storms.
Further research is needed on the breeding and foraging ecology of Pallas's fish eagle, ideally comparing nesting pairs located in healthy wetlands (e.g. Tangua Haor) and degraded wetlands in human-dominated landscapes, to determine factors that influence breeding success and juvenile dispersal. We recommend the development of a global action plan for the recovery of this threatened Asian raptor.

Acknowledgements We thank the Oriental Bird Club for supporting our fieldwork; Rhys Green and Rob Sheldon for their comments on the survey methods and reviewing a draft of this article; anonymous reviewers and M. Abdullah Abu Diyan for commenting on remote sensing; Syed Shahnoor Inam, Sourav Mahmud and Shafiqur Rahman for help during fieldwork; and the Bangladesh Forest Department for their support and encouragement.

Author contributions Funding acquisition, conceptualization, design, analysis and interpretation: SUC; fieldwork, data collection: all authors; writing: SUC; revision: SUC, MF.

\section{Conflicts of interest None.}

Ethical standards This research abided by the Oryx guidelines on ethical standards and national research guidelines of Bangladesh.

\section{References}

Ahmed, Z.U., M, A., Hassan, Z.N.T., Begum, M., Khondker, S.M.H., Kabir, M., Ahmad, A.T.A. et al. (2009) Encyclopedia of Flora and Fauna of Bangladesh, Vol. 9. Angiosperms: Dicotyledons (Magnoliaceae-Punicaceae). Asiatic Society of Bangladesh, Dhaka, Bangladesh.

Birdife International (2001) Threatened Birds of Asia: The BirdLife International Red Data Book. BirdLife International, Cambridge, UK.

Birdife International (2020) Species factsheet: Haliaeetus leucoryphus. datazone.birdlife.org/species/factsheet/pallass-fisheagle-haliaeetus-leucoryphus [accessed 15 May 2020].

Chowdhury, S.U. (2018) Nature Quest: a quest for eagle nest. The Daily Star, 23 February 2018. thedailystar.net/backpage/naturequest-quest-eagle-nest-1538788 [accessed 23 May 2020].

Crip s, J.R. (1878) First list of the birds of Fureedpore, eastern Bengal. Stray Feathers, 7, 238-315.

Geisen, W., Khan, N., Shahid, A. \& Rahman, A. (2000) Management Plan for Tanguar Haor, Bangladesh. Achieving Community-Based Sustainable Use of Wetland Resources. National Conservation Strategy Implementation Project 1, Dhaka, Bangladesh.

Gilbert, M., Tingay, R., Losolmaa, J., Sureda, N., Gilbert, C., Batmunkh, D. \& Gombobaatar, S. (2014) Distribution and status of the Pallas's fish eagle Haliaeetus leucoryphus in Mongolia: a cause for conservation concern? Bird Conservation International, $24,379-388$.

HAQUE, M.I. \& BASAK, R. (2017) Land cover change detection using GIS and remote sensing techniques: a spatio-temporal study on Tanguar Haor, Sunamganj, Bangladesh. The Egyptian Journal of Remote Sensing and Space Science, 20, 251-263.

Hardey, J. (2006) Raptors: A Field Guide to Survey and Monitoring. The Stationery Office, London, UK.

Harris, G., Farley, S., Russell, G.J., Butler, M.J. \& Selinger, J. (2013) Sampling designs matching species biology produce accurate and affordable abundance indices. PeerJ, 227, 1-26. 
Jones, J.P., Andriamarovololona, M.M., Hockley, N., Gibbons, J.M. \& Milner-Gulland, E.J. (2008) Testing the use of interviews as a tool for monitoring trends in the harvesting of wild species. Journal of Applied Ecology, 45, 1205-1212.

Leroux, L., Congedo, L., Bellón, B., Gaetano, R. \& Bégué, A. (2018) Land cover mapping using Sentinel-2 images and the semi-automatic classification plugin: a northern Burkina Faso case study. QGIS and Applications in Agriculture and Forest, 2, 119-151.

McKelvey, K.S., Aubry, K.B. \& Schwartz, M.K. (2008) Using anecdotal occurrence data for rare or elusive species: the illusion of reality and a call for evidentiary standards. BioScience, 58, 549-555.

Miron, M.K. \& Chowdhury, S.U. (2019) Breeding density and habitat selection of the grey-headed fish-eagle in Noakhali District, Bangladesh. Journal of Raptor Research, 53, 134-141.

MoEF (2019) The 6th National Report to the Convention on Biological Diversity. Ministry of Environment, Forest and Climate Change, Dhaka, Bangladesh.

Muzaffar, S.B. \& Ahmed, F.A. (2007) The effects of the flood cycle on the diversity and composition of the phytoplankton community of a seasonally flooded Ramsar wetland in Bangladesh. Wetlands Ecology and Management, 15, 81-93.

Naher, H. \& Khan, S.I. (2009) Breeding of Pallas's fish eagle (Haliaeetus leucoryphus), an endangered bird of Bangladesh. Bangladesh Journal of Zoology, 37, 95-102.

NaOroj, R. (2006) Birds of Prey of the Indian Subcontinent. Om Books International, New Delhi, India.

Nash, H.C., Wong, M.H. \& Turvey, S.T. (2016) Using local ecological knowledge to determine status and threats of the Critically Endangered Chinese pangolin (Manis pentadactyla) in Hainan, China. Biological Conservation, 196, 189-195.

Newing, H. (2011) Conducting Research in Conservation: A Social Science Perspective. Routledge, Abingdon, UK.

Newton, I. (1979) Population Ecology of Raptors. T \& AD Poyser, London, UK.

QGiS Development Team (2016) QGIS Geographic Information System. Open Source Geospatial Foundation Project. qgis.org/en/site [accessed 1 July 2021].

R Core Team (2016) R: A Language and Environment for Statistical Computing. R Foundation for Statistical Computing, Vienna, Austria.

Rahmani, A.R., Kalra, M. \& Khan, N.I. (2012) Threatened Birds of India: Their Conservation Requirements. Oxford University Press, Oxford, UK.
Ramsar Convention Secretariat (2007) Designating Ramsar Sites: The Strategic Framework and Guidelines for the Future Development of the List of Wetlands of International Importance. Ramsar Handbooks for the Wise Use of Wetlands. Ramsar Convention Secretariat, Gland, Switzerland.

Salauddin, M. \& Islam, A.K.M.S. (2011) Identification of land cover changes of the Haor area of Bangladesh using Modis images. In Proceedings of the 3rd International Conference on Water \& Flood Management, 8-10 January 2011, Dhaka, Bangladesh. Institute of Water and Flood Management, Bangladesh University of Engineering Technology, Dhaka, Bangladesh.

Sarkar, S., Khan, S.U., Mikolon, A., Rahman, M.Z., Abedin, J., Zeidner, N. et al. (2017) An epidemiological study of avian influenza $\mathrm{A}\left(\mathrm{H}_{5}\right)$ virus in nomadic ducks and their raising practices in northeastern Bangladesh, 2011-2012. Influenza and other Respiratory Viruses, 11, 275-282.

Siddiqui, K.U., Islam, M.A., Kabir, S.M.H., Ahmad, M., Ahmed, A.T.A., Rahman, A. et al. (2008) Encyclopaedia of Flora and Fauna of Bangladesh, Vol. 26: Birds. Asiatic Society of Bangladesh, Dhaka, Bangladesh.

Sourav, S.H., Ahmed, B. \& Thompson, P.A. (2011) Pallas's fish eagle Haliaeetus leucoryphus in Bangladesh. Birding ASIA, $16,101-105$.

Steele, M.L. (2017) Where in the world are Pallas's fish eagles? Migration and ecology of Haliaeetus leucoryphus in Asia. $\mathrm{PhD}$ thesis, University of Arkansas, Fayetteville, USA.

Turvey, S.T., Bryant, J.V., Duncan, C., Wong, M.H., Guan, Z., FEI, H. et al. (2016) How many remnant gibbon populations are left on Hainan? Testing the use of local ecological knowledge to detect cryptic threatened primates. American Journal of Primatology, 79, 1-13.

Turvey, S.T., Fernández-Secades, C., Nuñez-Miño, J.M., Hart, T., Martinez, P., Brocca, J.L. \& Young, R.P. (2014) Is local ecological knowledge a useful conservation tool for small mammals in a Caribbean multicultural landscape? Biological Conservation, $169,189-197$.

USGS (U.S. Geological Survey) (2020) Earth Explorer. earthexplorer.usgs.gov [accessed 20 May 2020].

Warkentin, I.G. \& Hernández, D. (1996) The conservation implications of site fidelity: a case study involving NearcticNeotropical migrant songbirds wintering in a Costa Rican mangrove. Biological Conservation, 77, 143-150. 